\title{
Cloning and Sequence Determination of Six Staphylococcus aureus $\beta$-Lactamases and Their Expression in Escherichia coli and Staphylococcus aureus
}

\author{
By ALISON K. EAST AND K. G. H. DYKE* \\ Microbiology Unit, Department of Biochemistry, University of Oxford, South Parks Road, \\ Oxford OXI $3 Q U, U K$
}

(Received 23 September 1988; revised 11 January 1989; accepted 12 January 1989)

\begin{abstract}
The plasmid-encoded $\beta$-lactamase genes of six strains of Staphylococcus aureus were cloned and shown to be expressed in Escherichia coli. The cloned genes were re-introduced into $S$. aureus via a shuttle vector, and expressed $\beta$-lactamase. However, clones containing only the small amount of DNA found necessary for expression of ampicillin resistance in $E$. coli did not express $\beta$ lactamase in $S$. aureus. Much larger pieces of DNA from the original plasmid were necessary to obtain expression in $S$. aureus. Some of the six strains of $S$. aureus synthesized $\beta$-lactamase constitutively and some released only a small proportion of the enzyme into the medium. Both these characteristics were maintained in the clones so it is concluded that they are features either of the gene itself or of the surrounding DNA. The cloned genes were sequenced and the putative amino acid sequences of the $\beta$-lactamases were compared. There are several differences betwe en the sequences and in particular one change in the $\mathrm{N}$-terminal region, at a position believed to be especially important for export of proteins from the cell, is thought to have a key effect on whether or not the enzyme is found in the medium.
\end{abstract}

\section{INTRODUCTION}

Resistance of Staphylococcus aureus to $\beta$-lactam antibiotics is an important clinical problem. This resistance is commonly conferred by production of a $\beta$-lactamase, an enzyme which cleaves the $\beta$-lactam ring, rendering the molecule inactive as an antibiotic. In $S$. aureus this enzyme is often encoded on a plasmid of approximately $30 \mathrm{~kb}$ which frequently carries genes conferring resistance to ions such as cadmium, lead, antimony, mercury, arsenate and arsenite. Genes conferring resistance to antibiotics are frequently found on plasmids. One reason for this may be that the genes are more 'mobile' than those of the chromosome; plasmids can be transferred between strains by methods such as conjugation (Forbes \& Schaberg, 1983), transduction (Shalita et al., 1980) and phage-mediated transfer (Lacey, 1980). The $\beta$-lactamase gene has also been described as part of a transposon (Asheshov, 1966; Shalita et al., 1980; Lyon \& Skurray, 1987).

A classification of $\beta$-lactamases into classes I-V was proposed by Richmond \& Sykes (1973). It is based mainly on enzymes from Gram-negative bacteria, and $\beta$-lactamases of Gram-positive organisms, including $S$. aureus, do not fit particularly well into this system. Ambler (1980) proposed a classification of $\beta$-lactamases based on amino acid sequence. At that time the amino acid sequence was known of five $\beta$-lactamases ( $S$. aureus, Bacillus cereus $569 \mathrm{H}$, Bacillus licheniformis and Escherichia coli RTEM and pBR322; see Ambler, 1979) which were clearly homologous and so were classified together as class A. Further studies have shown that these enzymes, grouped together by sequence homology, are similar mechanistically, in structure and often in their location, for example, membrane bound or extracellular.

Abbreviation: CBAP, 2-(2'-carboxyphenyl)-benzoyl-6-aminopenicillanic acid. 
The $\beta$-lactamases of $S$. aureus have been classified immunologically into types A-D, by reaction with antisera raised against a purified extracellular staphylococcal $\beta$-lactamase (Richmond, 1965a). This serological typing puts the enzymes into groups which show different kinetic characteristics. The $\beta$-lactamases of types $\mathrm{A}$ and $\mathrm{C}$ show high hydrolytic activity, which is increased on interaction with antibody. These are commonly found in strains which are frequently isolated from hospitals (Dyke \& Richmond, 1967) while strains producing the less hydrolytically active type B are far less frequently isolated from hospitals. The more recently described D-type $\beta$-lactamase (Rosdahl, 1973) shows fairly high hydrolytic activity and some increase when treated with antisera. It is commonly found associated with resistance to fusidic acid (Lacey \& Grinsted, 1972). These different $\beta$-lactamases are believed to be closely related and differences in reaction with antibody and the rate of hydrolysis of $\beta$-lactams are thought to be the result of small changes in amino acid sequence (Richmond, 1965a).

The expression of $\beta$-lactamase in $S$. aureus is either constitutive or inducible by $\beta$-lactams and their analogues. The molecular mechanism of induction is not known although expression was concluded to be negatively controlled by a repressor protein (Richmond, 1965 b). On transduction of the $\beta$-lactamase plasmid to another strain the expression of the gene, i.e. constitutive or inducible, is unchanged, indicating that the control of expression is plasmid-encoded (K. G. H. Dyke, unpublished results). The region responsible for control of $\beta$-lactamase expression has been mapped adjacent to the $\beta$-lactamase structural gene (Novick \& Richmond, 1965).

Strains of $S$. aureus expressing $\beta$-lactamase isolated from hospitals during $1960-1970$ could be divided into two groups: those which encoded a $\beta$-lactamase found almost completely associated with the cell and those in which a high percentage of the enzyme activity was found in the medium in which the cells were growing. The latter were frequently isolated from hospitals, i.e. were endemic, while those in which the majority of enzyme activity was cell associated were not (Dyke et al., 1970). Some of the $\beta$-lactamase-encoding plasmids were transduced into another strain of $S$. aureus and the percentage of activity in the media was the same in both strains, suggesting that whether the $\beta$-lactamase activity is cell associated or found in the medium is a property of the plasmid rather than the chromosomal 'background' of the strain (K. G. H. Dyke, unpublished results).

Gram-positive organisms, including $S$. aureus, have a simple peptidoglycan cell wall and do not possess an outer membrane bound periplasmic space. In Gram-positive organisms once a protein has been exported from the cell and released from the membrane, it is found in the medium in which the cells are growing. The $\beta$-lactamases of the Gram-positive organisms $B$. licheniformis, $B$. cereus and $S$. aureus have been shown to occur in a membrane-bound form (Nielsen \& Lampen, 1982). Each $\beta$-lactamase contains an $\mathrm{N}$-terminal extension, missing from the mature extracellular protein, which contains the cysteine residue by which the protein is attached to the membrane. The membrane attachment is by a glyceride thioether modification, identical to that of several outer-membrane proteins of the Gram-negative $E$. coli (Nielsen \& Lampen, 1982). The extracellular form is thought to be a cleavage product of this membranebound form.

In this study, six strains of $S$. aureus containing a $\beta$-lactamase-expressing plasmid were investigated. The strains express $\beta$-lactamases of different immunological groups, are constitutively or inducibly expressed and have a characteristic proportion of the enzyme released to the medium in which the cells are growing. The $\beta$-lactamase genes were cloned in $E$. coli and the DNA sequenced to compare the amino acid sequences of the different $\beta$-lactamases. Restriction fragments of the staphylococcal plasmids were cloned in $S$. aureus, using $S$. aureus/E. coli shuttle vectors, to investigate the control of expression and the proportion of $\beta$-lactamase in the medium of isolated fragments of DNA, as distinct from the entire staphylococcal plasmids.

\section{METHODS}

Bacterial strains and plasmids. The $\beta$-lactamase-producing strains of $S$. aureus used are shown in Table 1. The $S$. aureus strains RN4220 (Kreiswirth et al., 1983) and 8325N (Novick \& Roth, 1968) were used as the recipients in $S$. aureus transformation experiments. The $S$. aureus plasmid pCW59 (Wilson et al., 1981) was used to clone directly in $S$. aureus. It carries determinants for resistance to tetracycline and chloramphenicol, with a single $B g / I I$ site 
焉

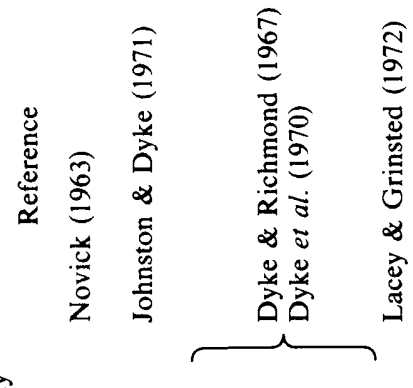

当突

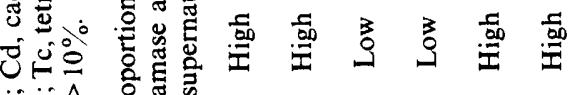

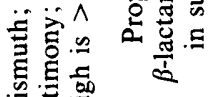

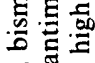

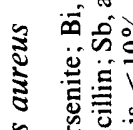

今

安产

Q

ड़े

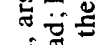

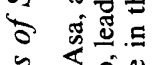

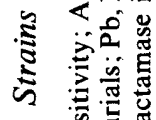

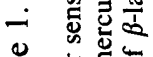

$$
\text { उ }
$$

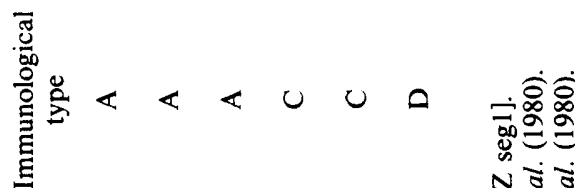

ㄱำ

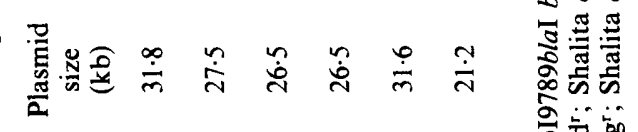

号

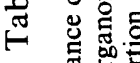

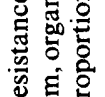

究芒

0

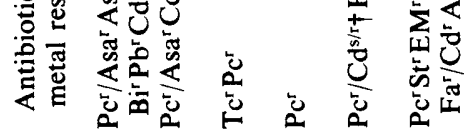

을

列

究这

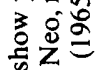

范泀 吾

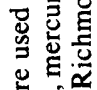

के

更?

흘

응

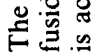

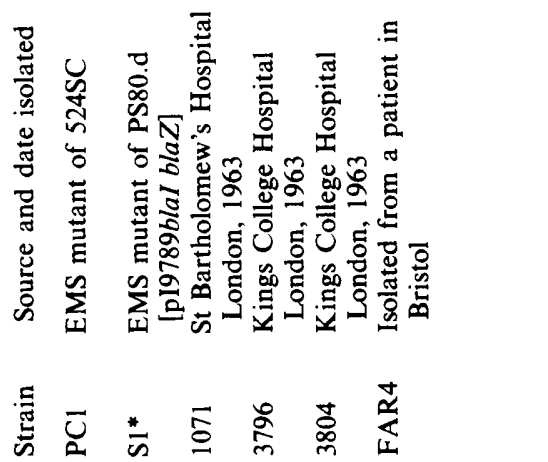


within the latter determinant. The $S$. aureus plasmid pE194 (Horinouchi \& Weisblum, 1982) was used to construct the $S$. aureus/E. coli shuttle vectors. This plasmid expresses resistance to erythromycin in both $E$. coli and $S$. aureus.

E. coli strain MC1061 (Casadaban \& Cohen, 1980) was used as a recipient for transformation and JM107 (Yanisch-Perron et al., 1985) was used for transformations involving lacZ' expression of the vector for selection of recombinants. The plasmid pRW33 (Mézes et al., 1983) was used to clone in E. coli. This plasmid carries determinants encoding resistance to chloramphenicol and tetracycline, with a single EcoRI site in the former and single HindIII, BamHI, Sall and HincII sites within, or affecting expression of the latter. Plasmids pUC18 and pUC19 (Yanisch-Perron et al., 1985) and pJS62 were used with pE194 in the construction of shuttle vectors. Plasmid pJS62 (a gift from J. Sutherland) was constructed by cloning a gene conferring to chloramphenicol into the $S c a$ I site of the ampicillin-resistance-conferring gene of a modified pUC19. The resulting plasmid is $\mathrm{Cm}^{\mathrm{r}}$ and $\mathrm{Ap}^{\mathrm{s}}$. It contains the unique polylinker cloning sites, but the insert introduces a second EcoRI site (J. Sutherland, personal communication).

Media and reagents. For $S$. aureus, CY medium (Novick, 1963) was used for growth of cultures in liquid. CY solidified with $2 \%(\mathrm{w} / \mathrm{v})$ agar was used as solid medium, supplemented as appropriate with chloramphenicol $(10 \mu \mathrm{g}$ $\left.\mathrm{ml}^{-1}\right)$, erythromycin $\left(20 \mu \mathrm{g} \mathrm{ml}^{-1}\right)$, tetracycline $\left(5 \mu \mathrm{g} \mathrm{ml}^{-1}\right)$, starch $(0 \cdot 4 \%$, w/v) and 2-(2'-carboxyphenyl)-benzoyl-6aminopenicillanic acid (CBAP) $\left(5 \mu \mathrm{g} \mathrm{ml}^{-1}\right)$.

For E. coli, LB medium (Maniatis et al., 1982) was used, and for plates, this was solidified with $2 \%$ agar. The following additions were used in the plates when appropriate: ampicillin $\left(50 \mu \mathrm{g} \mathrm{ml}^{-1}\right)$, tetracycline $\left(12.5 \mu \mathrm{g} \mathrm{ml}^{-1}\right)$, chloramphenicol $\left(10 \mu \mathrm{g} \mathrm{ml}^{-1}\right)$ and erythromycin $\left(100 \mu \mathrm{g} \mathrm{ml}^{-1}\right)$.

Growth was at $37^{\circ} \mathrm{C}$ under aerobic conditions, except for experiments involving $S$. aureus strain $\mathrm{S} 1$ which was grown aerobically at $30^{\circ} \mathrm{C}$.

Restriction enzymes were from Amersham, Bethesda Research Laboratories (BRL) or New England Biolabs. DNA ligase (from bacteriophage T4) was obtained from Boehringer Corporation Ltd. (BCL) and Klenow fragment from Pharmacia. All enzymes were used according to the manufacturer's instructions. CBAP was obtained from Sigma and nitrocefin from Glaxo-Allenburys Research, Greenford, UK.

Preparation of plasmid DNA and recombinant DNA techniques. The method of Novick \& Bouanchaud (1971) was used to purify plasmid DNA from $S$. aureus for restriction enzyme analysis and cloning. Transformation of $8325 \mathrm{~N}$ and RN4220 protoplasts was as described by Lindberg (1981). E. coli DNA was prepared by the alkaline lysis method, described by Maniatis et al. (1982). Transformation of $E$. coli MC1061 was carried out using the method of Casadaban \& Cohen (1980) and that of JM107 according to the method described in the Amersham M13 Cloning and Sequencing Handbook.

Electrophoresis. Plasmid DNA and restriction-enzyme-digested DNA were electrophoresed through gels of $1 \%$ $(w / v)$ agarose in TBE buffer $(500 \mathrm{mM}$-Tris, $500 \mathrm{~mm}$-boric acid, $100 \mathrm{~mm}$-EDTA) containing $500 \mu \mathrm{g}$ ethidium bromide $1^{-1}$. The DNA bands were visualized on a UV transilluminator and photographed.

DNA sequencing. The clones for sequencing were made by cloning in M13mp18 and M13mp19 (Messing et al., 1977), or in plasmids pUC18, pUC19 and pJS62. The sequencing was done by the dideoxynucleotide chain termination method of Sanger et al. (1977). For M13 clones this was as described in the Amersham M13 Cloning and Sequencing Handbook and universal and 'far' primer (Pharmacia), and an oligonucleotide ( $5^{\prime}$-TTCAAACAGTCCACATGCC-3'), complementary to part of the $\beta$-lactamase gene (near the $5^{\prime}$ end), were used as primers. Sequencing primer was annealed to the single-stranded M13 template DNA by heating the annealing mixture at $100^{\circ} \mathrm{C}$ for $3 \mathrm{~min}$ and then allowing at least $15 \mathrm{~min}$ for it to cool to room temperature (New England Biolabs Sequencing Manual). For sequencing double-stranded plasmid clones the method of Korneluk et al. (1985) was used. In addition to the other primers, reverse primer (BCL) was also used to sequence plasmid DNA. Sequencing reactions were done with $\left[\alpha^{35} \mathrm{~S}\right] \mathrm{dATP}$ (Amersham) at $37^{\circ} \mathrm{C}$. All nucleotides were from BCL.

Purification of oligonucleotide. The oligonucleotide was obtained from the Dyson-Perrins Laboratory, Oxford. The oligonucleotide solution was heated overnight at $55^{\circ} \mathrm{C}$ and then cooled on ice. The solution was dried down under vacuum and resuspended in sterile water. To assess the purity of the oligonucleotide preparation it was labelled using $\left[\gamma^{-32} \mathrm{P}\right]$ ATP (Amersham) and T4 polynucleotide kinase (Amersham) as described by Carter $e$ t al.

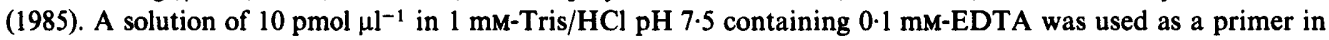
sequencing reactions.

Assay of $\beta$-lactamase activity. An overnight culture of $S$. aureus was diluted 1 in 100 in fresh CY broth and grown aerobically, following the $\mathrm{OD}_{675}$ as a measure of growth. After $1 \mathrm{~h}$, if required, CBAP was added to a final concentration of $7.5 \mu \mathrm{M}$. Samples were taken by removing $1 \mathrm{ml}$ of culture, adding $150 \mu \mathrm{l}$ 8-hydroxyquinoline and microfuging for $5 \mathrm{~min}$. The supernatant was decanted to a fresh tube and the pellet resuspended in $1 \mathrm{ml} \mathrm{CY}$ and $150 \mu 1$ 8-hydroxyquinoline. The supernatant and pellet fractions were assayed for $\beta$-lactamase activity at $37^{\circ} \mathrm{C}$, in a cuvette containing $0.1 \mathrm{mg}$ nitrocefin in $0.05 \mathrm{M}$-phosphate buffer $\mathrm{pH} 7.0$ to which the sample was added (usually 10-50 $\mu \mathrm{l})$. The $A_{482}$ was followed and the activity of each sample determined in $\mu$ mol product produced $\mathrm{min}^{-1}(\mathrm{mg}$ dry weight of cells $)^{-1}$.

$S$. aureus $\beta$-lactamase plate test. The test used was a modification of the method of Dyke et al. (1966). Colonies 
grown on starch plates (either with or without CBAP) were covered by a solution of penicillin $\mathrm{G}(0.5 \mathrm{~g}), 0 \cdot 1 \mathrm{M}-$ phosphate buffer $\mathrm{pH} 7.0(20 \mathrm{ml})$ and stock iodine solution $(5 \mathrm{ml})$. The solution was poured off the plate and the colonies producing $\beta$-lactamase were identified by their white haloes, which appeared after approximately $30 \mathrm{~s}$ incubation at $25^{\circ} \mathrm{C}$.

\section{RESULTS}

Cloning in E. coli

The $\beta$-lactamase gene was cloned from purified $S$. aureus plasmid DNA, prepared from the strains shown in Table 1 , using the vector $\mathrm{pRW} 33$. The $\beta$-lactamase-encoding recombinant plasmids were selected on plates containing ampicillin. A comparison of the largest $\beta$-lactamase-

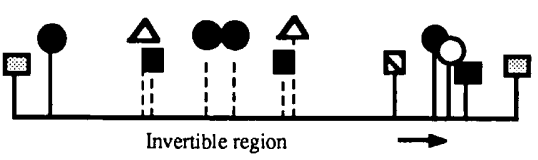

pPC1 (pAE201)

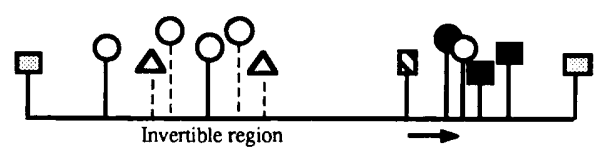

pS1 (pAE301)

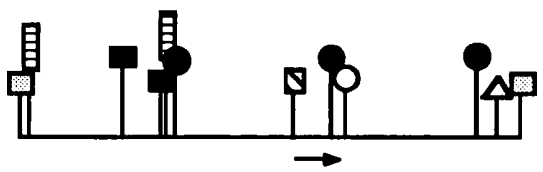

p11071 (pAE101)

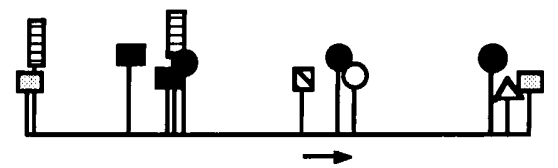

pI3796 (pAE501)

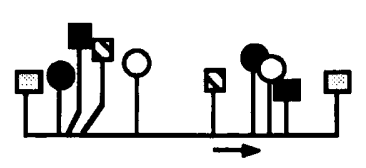

pII3804 (pAE401)

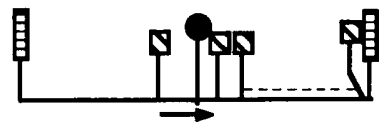

pUB101 (pAE601)

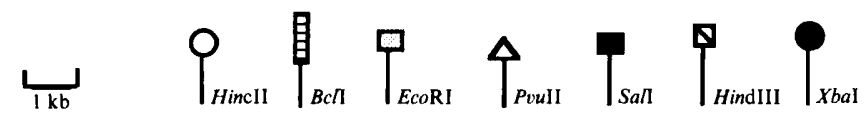

Fig. 1. Comparison of fragments from staphylococcal plasmids that contain the $\beta$-lactamase gene. The names in parentheses correspond to the names of the clones, containing the fragment shown, in E. coli. A dashed vertical line shows the position of a restriction site in one orientation in the invertible region and a dashed horizontal line indicates an incomplete map for HindIII. An arrow indicates the position and orientation of the $\beta$-lactamase gene. 


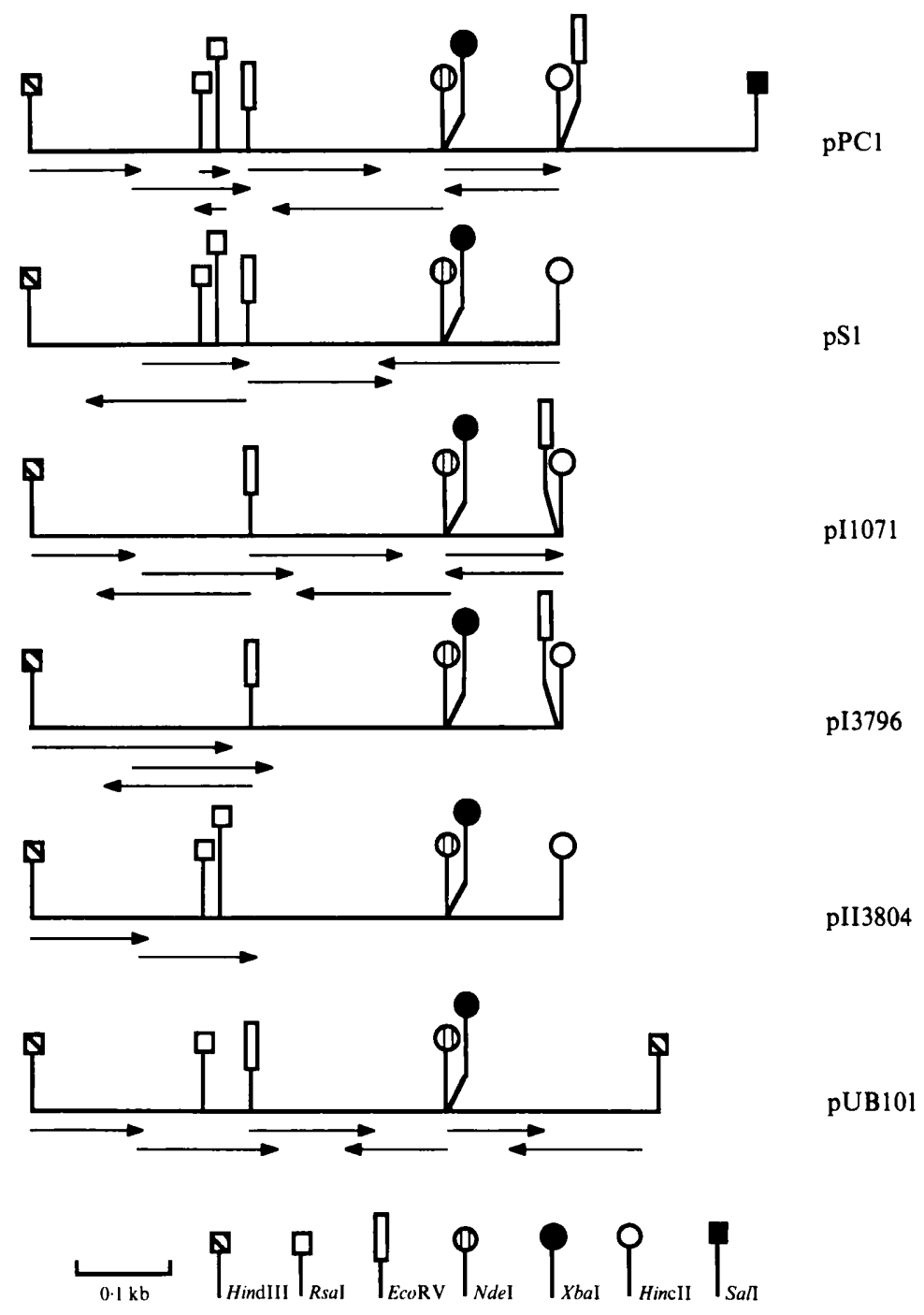

Fig. 2. The smallest fragments cloned from the staphylococcal plasmids conferring resistance to ampicillin in $E$. coli and the strategy used to sequence the $\beta$-lactamase genes. The arrows indicate the start and the extent of the sequences obtained from these clones.

producing fragments is shown in Fig. 1. The fragment of DNA containing the gene was made smaller by sub-cloning and a comparison of the smallest Apr clones obtained is shown in Fig. 2.

\section{Sequencing the $\beta$-lactamase genes}

The genes were sequenced using the strategy outlined for each in Fig. 2. The genes of pPCl, pS1, pI1071 and pUB101 were sequenced completely and their nucleotide sequence, together with the partial nucleotide sequence of pII3804 and pI3796 genes, is shown in Fig. 3. The amino acid sequence of the proteins is compared in Fig. 4.

\section{Cloning the $\beta$-lactamase genes in $S$. aureus}

The $\beta$-lactamase genes were cloned in $S$. aureus using two shuttle vectors for transfer of DNA between $E$. coli and $S$. aureus: pAE704 and pAE705 (Fig. 5). 
Table 2. $\beta$-Lactamase activity of staphylococcal plasmids and clones

\begin{tabular}{|c|c|c|c|c|c|c|}
\hline \multirow[b]{2}{*}{ Plasmid } & \multirow[b]{2}{*}{ Construction of plasmid } & & \multicolumn{2}{|c|}{ With inducer } & \multicolumn{2}{|c|}{ Without inducer } \\
\hline & & $\begin{array}{l}\text { Orientation } \\
\text { of insert* }\end{array}$ & $\begin{array}{c}\text { Total } \\
\text { activity } \dagger\end{array}$ & $\begin{array}{l}\text { Percentage } \\
\text { in medium }\end{array}$ & $\begin{array}{c}\text { Total } \\
\text { activity } \dagger\end{array}$ & $\begin{array}{l}\text { Percentage } \\
\text { in medium }\end{array}$ \\
\hline $\begin{array}{l}\text { pPC1 } \\
\text { pAE206 }\end{array}$ & pAE201 HincII PvuII/pAE704 SmaI PvuII & & 289 & $\begin{array}{c}28 \\
\text { oes not trans }\end{array}$ & $\begin{array}{r}249 \\
\text { form } S . \text { at }\end{array}$ & treus $^{18}$ \\
\hline pAE207 & pAE201 HincII $P v u I I / p A E 705 S m a I P v u I I$ & - & 41 & 18 & 39 & 22 \\
\hline $\begin{array}{l}\text { pS1 } \\
\text { pAE306 } \\
\text { pAE307 }\end{array}$ & $\begin{array}{l}\text { pAE301 HincII PvuII/pAE704 PvuII } \\
\text { pAE301 } H \text { incII } P v u I I / \text { pAE705 SmaI PvuII }\end{array}$ & - & $\begin{array}{l}607 \\
986 \\
242\end{array}$ & $\begin{array}{l}11 \\
55 \\
20\end{array}$ & $\begin{array}{l}6 \\
7 \\
5\end{array}$ & $\begin{array}{l}<1 \\
<1 \\
<1\end{array}$ \\
\hline $\begin{array}{l}\text { pI1071 } \\
\text { pAE110 } \\
\text { pAE115 } \\
\text { pAE116 } \\
\text { pAE117 } \\
\text { pAE118 }\end{array}$ & $\begin{array}{l}\text { pIl071 PvuII BclI/pCW59 BglII HaeIII } \\
\text { pAE101 HincII/pAE704 SmaI } \\
\text { pAE101 HinclI/pAE704 SmaI } \\
\text { pAE101 HincIl/pAE705 SmaI } \\
\text { pAE101 HincII/pAE705 SmaI }\end{array}$ & $\begin{array}{l}+ \\
- \\
-\end{array}$ & $\begin{array}{r}124 \\
77 \\
347 \\
385 \\
33 \\
254\end{array}$ & $\begin{array}{r}<1 \\
8 \\
<1 \\
<1 \\
<1 \\
<1\end{array}$ & $\begin{array}{l}3 \\
2 \\
6 \\
5 \\
5 \\
5\end{array}$ & $\begin{array}{l}<1 \\
<1 \\
<1 \\
<1 \\
<1 \\
<1\end{array}$ \\
\hline $\begin{array}{l}\text { pI3796 } \\
\text { pAE504 } \\
\text { pAE505 } \\
\text { pAE506 }\end{array}$ & $\begin{array}{l}\text { pAE501 HinclI/pAE704 SmaI } \\
\text { pAE501 HincII/pAE704 SmaI } \\
\text { pAE501 HincII/pAE705 SmaI }\end{array}$ & $\begin{array}{l}+ \\
- \\
-\end{array}$ & $\begin{array}{r}142 \\
310 \\
454 \\
18\end{array}$ & $\begin{array}{r}<1 \\
<1 \\
1 \\
<1\end{array}$ & $\begin{array}{l}4 \\
8 \\
9 \\
6\end{array}$ & $\begin{array}{l}<1 \\
<1 \\
<1 \\
<1\end{array}$ \\
\hline $\begin{array}{l}\text { pII3804 } \\
\text { pAE404 }\end{array}$ & pAE401 EcoRI/pAE704 EcoRI & + & $\begin{array}{r}77 \\
133\end{array}$ & $\begin{array}{l}23 \\
28\end{array}$ & $\begin{array}{r}<1 \\
3\end{array}$ & $\begin{array}{l}<1 \\
<1\end{array}$ \\
\hline
\end{tabular}

* Orientation of insert is described in the text.

$\dagger$ Total activity is expressed as $\mu \mathrm{mol}$ product produced $\min ^{-1}$ (mg dry wt of culture) $)^{-1}$ at $37^{\circ} \mathrm{C}$.

$\ddagger$ Construction of this plasmid is described in the text.

The isolated $\beta$-lactamase structural gene of pI1071 (cloned as a $1 \cdot 1 \mathrm{~kb}$ HindIII-Hincll fragment in pAE703), and that of pUB101 (cloned as a $1.3 \mathrm{~kb}$ HindIII fragment in pAE703), although conferring resistance to ampicillin in E. coli, were not expressed in $S$. aureus. However, when larger fragments of the staphylococcal plasmids were cloned in E. coli and then transferred to $S$. aureus, $\beta$-lactamase was expressed. The clones constructed are shown in Table 2.

The plasmids pAE115, pAE116, pAE117, pAE118, pAE504, pAE505 and pAE506 were constructed by cloning a fragment containing the $\beta$-lactamase gene into the $S m a I$ site of the vector (Fig. 5). The orientation is defined as "+' if the HindIII site of the polylinker of the vector is nearer to the $3^{\prime}$ end of the $\beta$-lactamase gene, and ' - 'if the HindIII site is nearer to the $5^{\prime}$ end of the gene.

In the construction of pAE206, the vector was cut with PvuII and SmaI; pAE201 was cut with HincII and PvuII. The HincII-PvuII $\beta$-lactamase-containing fragment of pAE201 is ligated to the following vector fragments: the PvuII-Smal fragment of pAE704 containing the erythromycin resistance determinant and the PvulI fragment encoding the $E$. coli origin of replication. In pAE206, which failed to transform $S$. aureus, the small PvuII-SmaI fragment from the vector, containing the polylinker, is missing. This fragment is also missing from plasmids pAE207 and pAE307. The orientation of the insert in both these plasmids is described as '- ', by analogy with the other clones, although the HindIII site of the polylinker, used to define the orientation, is lost.

Plasmid pAE306 has the insert cloned into the PvuII site (A) of vector pAE704 (Fig. 5).

One plasmid expressing $\beta$-lactamase in $S$. aureus was constructed by cloning directly in $S$. aureus. Plasmid pAE110 was made by cloning a $B c / I-P v u I I$ fragment of pI1071 in the staphylococcal plasmid pCW59.

Estimation was made of the $\beta$-lactamase activity of the parent staphylococcal plasmid and of the clones, in the supernatant and associated with the cell, grown in the presence and absence of inducer (Table 2). 
$\begin{array}{llll}-35 & -10 & * & 120\end{array}$ TAAACTATTG ACACCGATAT TACAATTG ATATTATTGA TTtATAAAAA TTACAACTGT ----A--- --------

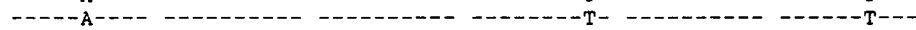

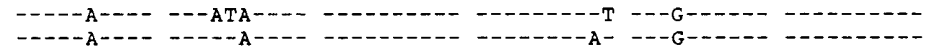
$S+D$ AATATCGGAG GGTTTATTTT GAAAAAGTTA ATATTTTTAA ITGTAATTGC TTTAGTTTTA

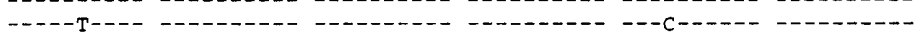

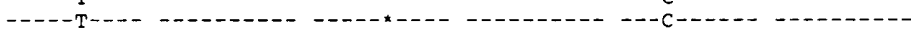

AGTGCATGTA ATTCAAACAG TTCACATGCC AAAGAGTTAA ATGATTTAGA AAAAAAATAT -

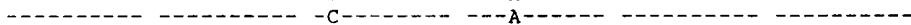

GAGGCTTCAA TGACATATAG TGATAATACA GCAAACAATA AAATTATAAA AGAAATCGGT GAG

660 AGATATGAGA TAGAATTAAA TTACTATTCA CCAAAGAGCA AAAAAGATAC TTCAACACCT - 


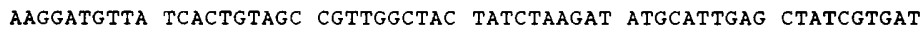

Fig. 3. The nucleotide sequence of the $\beta$-lactamase genes of (1) pPCl, (2) pS1, (3) pI 1071, (4) pI3796, (5) pII $3804,(6) \mathrm{pUB} 101$. The region coding for the $\beta$-lactamase is underlined. Restriction enzyme sites in any of the sequences are shown by a horizontal line above the top printed line. A dash in sequences (2)(6) means that the nucleotide is the same as the top printed line and a * within the sequence means that a base is missing. The position of the transcriptional and translational initiation signals ( $+D$ - ShineDalgarno sequence) are shown. The start of the mRNA is marked by $a *$ above the nucleotide sequence. 


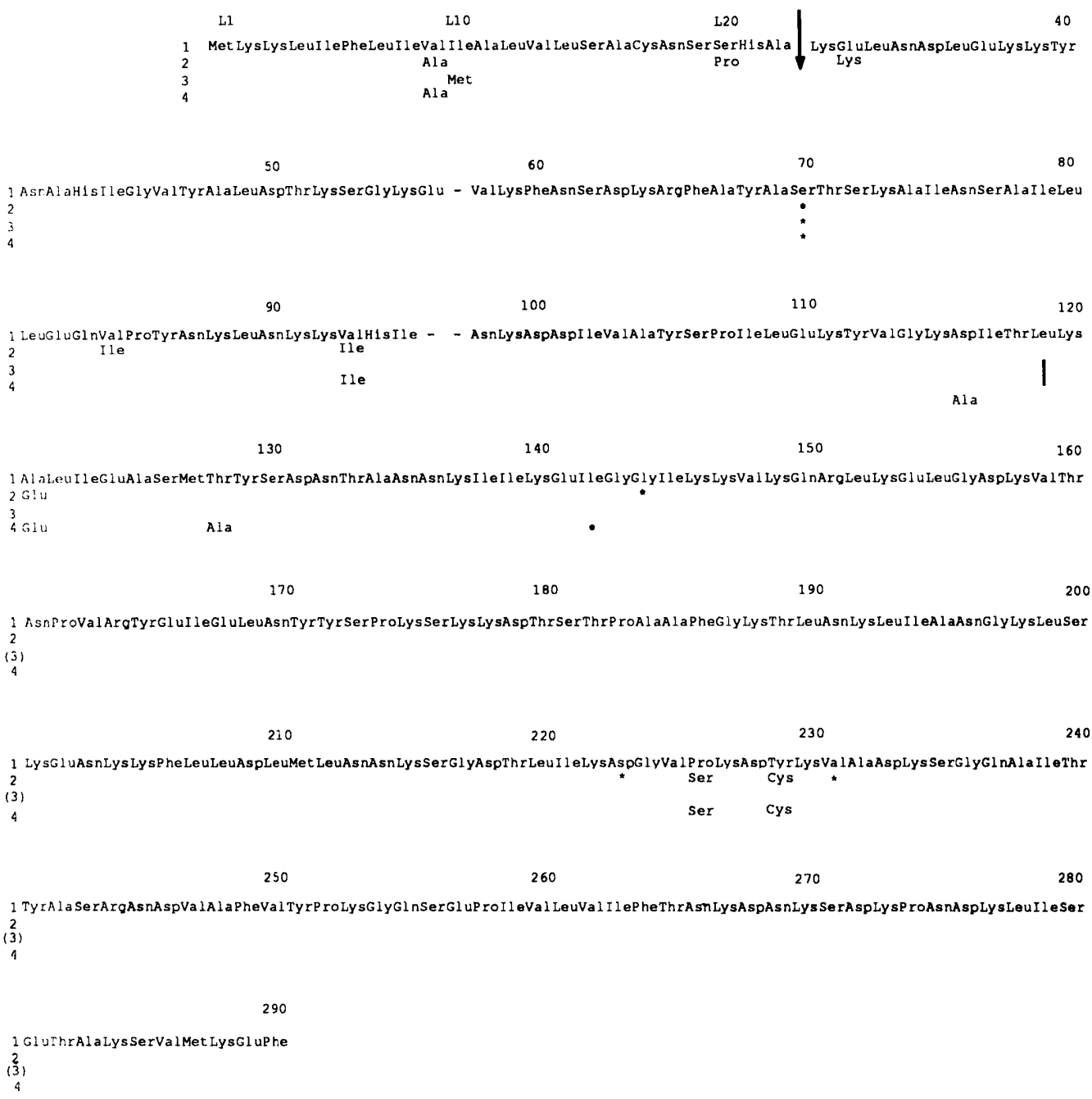

Fig. 4. The putative amino acid sequence of the staphylococcal $\beta$-lactamases. The sequences are: 1 , pPC1 and $\mathrm{pS} 1 ; 2$, pI1071; 3, pII3804 (up to amino acid 118 only); and 4, pUB101. For 2, 3 and 4 unless an amino acid change is indicated the sequence is the same as 1 . A vertical line shows the end of the data for pII 3804 and (3) indicates that there is no sequence data. A * indicates a silent change in the codon. The vertical arrow indicates the cleavage site at the end of the leader peptide. The mature protein is numbered according to Ambler (1979). The amino acids of the leader peptide are numbered from $\mathrm{L} 1$ to L22.

\section{DISCUSSION}

Chang \& Cohen (1974) cloned the $\beta$-lactamase gene from the staphylococcal plasmid pI 258 in $E$. coli and showed that it conferred resistance to ampicillin. All six staphylococcal $\beta$-lactamase genes used in the present study were expressed in $E$. coli even when the piece cloned from $S$. aureus included only 139 base pairs upstream of the translational start of the $\beta$-lactamase. The same piece did not permit expression of the gene when cloned back in $S$. aureus but fragments of DNA which also included upstream sequence sufficient to code for a second protein did permit such expression. This upstream DNA is being investigated to determine whether or not a second protein is required for expression. The constitutive or inducible expression of $\beta$-lactamase is determined, at least in part, by the fragment that could be expressed in $S$. aureus. Similarly, the proportion of the enzyme found in the medium is a characteristic of the cloned piece of DNA. 


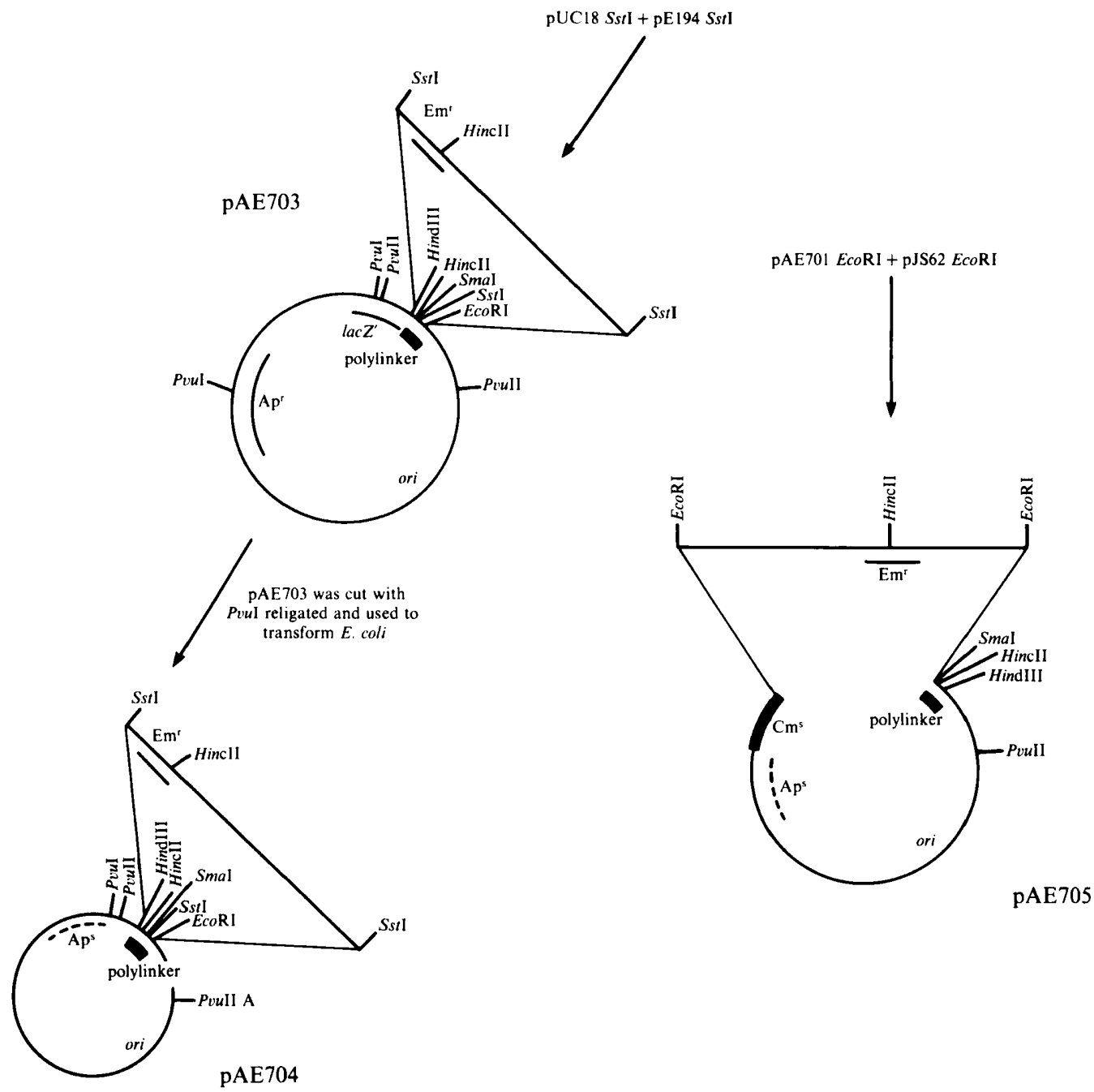

Fig. 5. Construction of ampicillin-sensitive shuttle vectors pAE704 and pAE705. The following are used to show phenotypic resistance ( $r$ ) or sensitivity (s): Ap, ampicillin; $\mathrm{Cm}$, chloramphenicol; Em, erythromycin; Tc, tetracycline. The E. coli origin of replication is marked ori. The PvuII site labelled 'A' is referred to in the text. Plasmid pAE701 was constructed in the following way. Plasmid pE194 was cut with $X b a \mathrm{I}$ and the ends filled in with Klenow, and ligated to pRW 33 cut with EcoRI and the ends filled in. The resultant $\mathrm{Tc}^{\mathrm{r}}, \mathrm{Em}^{\mathrm{r}}$ plasmid in $E$. coli was digested with EcoRI, ligated and used to transform $S$. aureus to $\mathrm{Em}^{\mathrm{r}}$. The plasmid obtained, pAE701, is pE194 with an additional single EcoRI site, outside the region coding for $\mathrm{Em}^{\mathrm{r}}$ and the origin of replication.

Comparison of the nucleotide sequence of the six staphylococcal $\beta$-lactamase genes (part only of pI3796) and pII3804) is very informative. The transcriptional control sequences at -35 (TTGACA) and - 10 (TATTAT) are identical for pI1071, pPC1, pUB101, pI3796, pII3804 and also for pI258 (Wang \& Novick, 1987). There are differences in the nucleotide sequences outside this region but the spacing between the transcriptional control signals is the same. There is another possible - 10 sequence (TAATAT) three nucleotides before the sequence marked as -10 in Fig. 3. The -10 sequence marked is that described by McLaughlin et al. (1981) for the pI258 $\beta$-lactamase and the start of the mRNA was shown by them to be the A, seven nucleotides downstream from the -10 . In plasmids pI1071, pPCl and $\mathrm{pI} 3796$ and $\mathrm{A}$ is also found at this position, whereas in pUB101 and pII3804 the A is replaced by a G. Purines are usually found at 
mRNA initiation sites and, in E. coli, A is more common than G (see Glass, 1982). A ShineDalgarno sequence (GGAGGG) occurs 22 nucleotides from the mRNA start site.

The nucleotide sequences of the coding region of the $\beta$-lactamase genes are highly conserved and all begin at a TTG codon. ATG is the most commonly found initiation codon but there are other cases of TTG as an initiation codon, for example, the sporulation gene gerA in Bacillus subtilis (Feavers et al., 1985). The open reading frame corresponds to a protein of 281 amino acids and, for $\mathrm{PPCl}$, includes at the C-terminal end the known sequence of the 257 amino acids for the extracellular PCl $\beta$-lactamase (Ambler, 1975). The derived amino acid sequences for the proteins from pPC1, pS1, pI1071 and pUB101, and for part of the protein of pII3804, are shown in Fig. 4 and they are very similar.

Nielsen \& Lampen (1982) described the processing of $\mathrm{PCl} \beta$-lactamase by a lipoprotein leader peptidase, involving membrane attachment by a thioether modification. The modification occurs at the cysteine at position L17. The target cleavage site of the lipoprotein leader peptidase is reported to be even more highly conserved than that of the leader peptidase and the amino acid sequence before the cysteine (-leucine-serine-alanine-cysteine-) of PCl $\beta$-lactamase fits with the consensus sequence described (Nielsen \& Lampen, 1982). This amino acid sequence is present in all the $\beta$-lactamase leader sequences examined here so that it is likely that similar processing occurs in these proteins.

The $\beta$-lactamases of pPC1, pS1 and pI 258 have identical amino acid sequences and so presumably behave indistinguishably. Within the $\mathrm{N}$-terminal region the $\beta$-lactamase of pUB101 has only one amino acid change, the conservative substitution of an alanine for a valine at L9 when compared with $\mathrm{pS1}$, and this does not alter the prediction, based on Chou \& Fasman $(1978 a, b)$, that this region will form a $\beta$-sheet. The substitution of a methionine in the $\beta$ lactamase of pII3804 at position L10 for the isoleucine found in the other $\beta$-lactamases increases the likelihood of an $\alpha$-helix formation but a $\beta$-sheet is still the predicted structure. The $\beta$ lactamase produced from pI 1071 is found in only very small amounts in the medium and differs from that of pUB101 at position L20 where a proline substitutes for the serine. This $\beta$-lactamase contains the site of thioether modification and therefore it is possible that it is the release of the enzyme from the membrane that is blocked. For $\mathrm{PCl}$ it is assumed that the protein is released from the membrane by cleavage by a peptidase after L22. It is thus a possibility that the presence of proline at L20, three amino acids before the cleavage site, in the $\beta$-lactamase of $\mathrm{pI} 1071$ is what prevents processing of the protein and hence results in very low amounts of $\beta$-lactamase in the medium. This is being investigated further by site-directed mutagenesis at this site.

Unlike the export of $\beta$-lactamases from Gram-positive organisms, export of $\beta$-lactamases from Gram-negative bacteria is reported to be by cleavage of a conventional leader peptide by a leader peptidase. This signal peptidase processing site of an $E$. coli $\beta$-lactamase has been extensively investigated (Plückthun \& Knowles, 1987) by deletion of amino acids and the results support the idea that the amino acids at the C-terminal end of the leader peptide are important for processing, in particular, the amino acid at the position equivalent to L20 in the staphylococcal $\beta$-lactamases. Plückthun \& Knowles (1987) also concluded that many different sequences are permitted at the start of the mature protein, so the lysine at position 32 may not affect processing although it is a very different amino acid from the glutamic acid that is found in this position for all the $\beta$-lactamases that are found in a high proportion in the medium. This conclusion must be contrasted with that for the coat protein of bacteriophage $\mathrm{fl}$, in which Russell \& Model (1981) and Boeke et al. (1980) showed that replacement of glutamic acid at this site by leucine or tyrosine slowed down the export of coat proteins.

The nucleotide sequence of the start of pI3796 $\beta$-lactamase is shown in Fig. 3. The sequence is identical to that of pI1071 except that in pI3796, following the TTG initiation codon there are only four As rather than five. The autoradiograph from a sequencing gel comparing $\mathrm{pPCl}$, pI1071 and pI3796 is shown in Fig. 6. The loss of a base introduces a 'frameshift' mutation in the third amino acid of the protein and a TAA stop codon follows directly. There does not seem to be another suitable initiation codon nearby, allowing a different translation 'start'. The DNA for sequencing was cloned directly into M13 from a clone, $\mathrm{Ap}^{\mathrm{r}}$ in $E$. coli, of $\mathrm{pI} 3796 \beta$-lactamase. If this is the correct sequence of this gene it is hard to explain how a functional $\beta$-lactamase is 
(a) (b) (c)

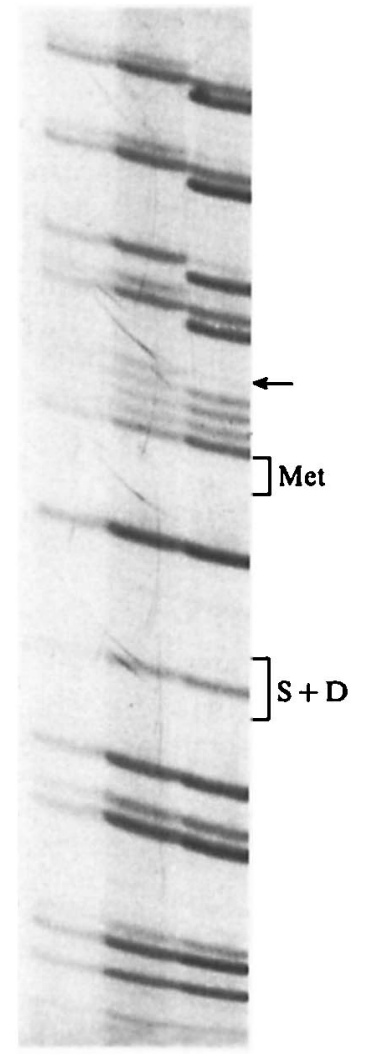

Fig. 6. 'A' track sequencing gel of plasmids pPCl $(a), \mathrm{pI} 1071(b)$ and $\mathrm{pI} 3796(c)$. The position of the Shine-Dalgarno sequence (S+D) and the first amino acid (Met) of the $\beta$-lactamase are shown. The position of the base deletion in pI 3796 is marked by an arrow.

produced from this DNA. Possible explanations might include: (i) ribosomal 'slippage' to compensate for the loss of a base; (ii) some unique tRNA, coded for in S. aureus and E. coli where the gene is expressed, allowing the recognition of two rather than three bases in an amino acid codon; (iii) a different codon is recognized as the start signal for translation of the protein; (iv) some aberration in the cloning. The last explanation can to some extent be ruled out because several clones have been sequenced and the region sequenced in both directions using independently made clones.

Within the mature protein sequence there are some differences in the amino acid sequences. The three-dimensional structure of the mature $\beta$-lactamase has been determined (Herzberg $\&$ Moult, 1987) and amino acid 121 is within an $\alpha$-helical region. Since this amino acid is alanine in $\mathrm{PCl}$ and pS1 $\beta$-lactamases and glutamic acid in those from pUB101 and pI1071 it would be expected that there would be a significant effect on folding. Glutamic acid is found in this position for class A $\beta$-lactamases from B. licheniformis, B. cereus $569 \mathrm{H}, E$. coli $\mathrm{pBR} 322$ and $E$. coli RTEM (Ambler, 1979) so that it is the $\mathrm{pPCl}$ and $\mathrm{pSI}$ proteins that are unusual. The serine at the active centre of class A proteins is conserved at position 70 for all the enzymes (Knott-Hunziker et al., 1979). Other non-conservative differences occur at positions 226 and 229 but are outside regions thought to form $\alpha$-helices (Herzberg \& Moult, 1987).

It was originally thought that the immunological classification using antibody raised against PCl $\beta$-lactamase was due to changes in the amino acid sequence of the proteins (Richmond, 1965 a). Plasmids $\mathrm{pI} 1071, \mathrm{pS1}$ and $\mathrm{pPCl}$ produce A-type $\beta$-lactamase, $\mathrm{pII} 3804$ produces $\mathrm{C}$-type 
(Dyke \& Richmond, 1967), while that of pUB101 was classified as D-type (Rosdahl, 1973). There are no amino acid changes that can be clearly correlated with this immunological classification. Perhaps other factors, such as the folding of the protein or the presence of other proteins, may contribute to the detected differences.

Downstream of the open reading frame there are no obvious transcription termination signals in any of the plasmids for which the nucleotide sequence has been obtained. It is clear that soon after the end of the gene, homology between the nucleotide sequences diminishes. Plasmids which are known to be closely related, such as $\mathrm{pPCl}, \mathrm{pS1}$ and $\mathrm{pI} 258$, have identical downstream sequences, including a direct repeat of a sequence found in only one copy in pI1017 (Fig. 3). The sequence of pUB 101 is very different from all the other plasmids 14 nucleotides after the translational stop signal (Fig. 3). It still remains a possibility that the $\beta$-lactamase structural gene is the first of an operon and therefore the transcriptional stop is a considerable distance downstream.

A. K.E. was a recipient of an SERC Studentship for training in research methods.

\section{REFERENCES}

AMbler, R. P. (1975). Amino-acid sequence of Staphylococcus aureus penicillinase. Biochemical Journal 151, 197-218.

Ambler, R. P. (1979). Amino acid sequences of $\beta$ lactamases. In Beta-Lactamases, pp. 99-127. Edited by J. M. T. Hamilton-Miller \& J. T. Smith. London : Academic Press.

AMbler, R. P. (1980). The structure of $\beta$-lactamases. Philosophical Transactions of the Royal Society of London B289, 321-331.

Asheshov, E. H. (1966). Chromosomal location of the genetic elements controlling penicillinase production in a strain of Staphylococcus aureus. Nature, London 210, 804-806.

Boeke, J. D., Russel, M. \& Model, P. (1980). Processing of filamentous phage pre-coat protein (effect of sequence variations near the signal peptidase cleavage site). Journal of Molecular Biology 144, 103-116.

Carter, P., Bedouelle, H., Waye, M. M. Y. \& WINTER, G. (1985). Oligonucleotide Site-directed Mutagenesis in M13. Colchester: Anglian Biotechnology.

Casadaban, M. J. \& Cohen, S. N. (1980). Analysis of gene control signals by DNA fusion and cloning in Escherichia coli. Journal of Molecular Biology 138, 179-207.

Chang, A. C. Y. \& Cohen, S. N. (1974). Genome construction between bacterial species in vitro: replication and expression of Staphylococcus plasmid genes in Escherichia coli. Proceedings of the National Academy of Sciences of the United States of America 71, 1030-1034.

Chou, P. Y. \& Fasman, G. D. (1978a). Prediction of the secondary structure of proteins from their amino acid sequence. Advances in Enzymology 47, 45148.

Chov, P. Y. \& Fasman, G. D. (1978b). Empirical predictions of protein conformation. Annual Review of Biochemistry 47, 251-276.

Dyke, K. G. H., Jevons, P. M. \& Parker, M. T. (1966). Penicillinase production and intrinsic resistance to penicillins in Staphylococcus aureus. Lancet $\mathrm{i}$, 835-838.
DYKe, K. G. H. \& Richmond, M. H. (1976). Occurrence of various types of penicillinase plasmids among hospital staphylococci. Journal of Clinical Pathology 20, 75-79.

Dyke, K. G. H., PARKer, M. T. \& Richmond, M. H. (1970). Penicillinase production and metal-ion resistance in Staphylococcus aureus cultures isolated from hospital patients. Journal of Medical Microbiology 3, 125-136.

Feavers, I. M., Miles, J. S. \& Molr, A. (1985). The nucleotide sequence of a spore germination gene (gerA) of Bacillus subtilis. Gene 38, 95-102.

ForeEs, B. A. \& SCHABERG, D. R. (1983). Transfer of resistance plasmids from Staphylococcus epidermidis to Staphylococcus aureus: evidence for conjugative exchange of resistance. Journal of Bacteriology 153, 627-634.

Glass, R. E. (1982). Gene Function: E. coli and its Heritable Elements, pp. 60-64. London: Croom Helm.

HERZBERG, O. \& Moult, J. (1987). Bacterial resistance to $\beta$-lactam antibiotics: crystal structure of $\beta$ lactamase from Staphylococcus aureus $\mathrm{PCI}$ at $2.5 \AA$ resolution. Science 236, 694-701.

HorinOUCHI, S. \& Weisblum, B. (1982). Nucleotide sequence and functional map of pE194, a plasmid that specifies inducible resistance to macrolide, lincosamide and streptogramin type B antibiotics. Journal of Bacteriology 150, 804-814.

JoHNSTON, L. H. \& DYKE, K. G. H. (1971). Stability of penicillinase plasmids in Staphylococcus aureus. Journal of Bacteriology 107, 68-73.

KnotT-Hunziker, V., Waley, S. G., Orlek, B. S. \& Sammes, P. G. (1979). Penicillinase active sites: labelling of serine-44 in $\beta$-lactamase I by $6 \beta$ bromopenicillanic acid. FEBS Letters 99, 59-61.

Korneluk, R. G., QuaN, F. \& Gravel, R. A. (1985). Rapid and reliable dideoxy sequencing of doublestanded DNA. Gene 40, 317-323.

KREISWIRTH, B. H., Löfdahl, S., Betley, M. J., O'Reilly, M., SChleIVERT, P. M., Bergdoll, M. S. \& Novick, R. P. (1983). The toxic shock syndrome exotoxin is not detectably transmitted by a prophage. Nature, London 305, 709-712. 
LACEY, R. W. (1980). Bacteriophages and the spread of resistance in Staphylococcus aureus. Journal of Antimicrobial Chemotherapy 6, 567-568.

LACEY, R. W. \& GRINSTED, J. (1972). Linkage of fusidic acid resistance to the penicillinase plasmid in Staphylococcus aureus. Journal of General Microbiology 73, 501-508.

LiNDBERG, M. (1981). Genetic studies in Staphylococcal aureus using protoplasts: cell fusion and transformation. In Staphylococci and Staphylococcal Infections (Zentralblatt für Bakteriologie suppl. 10), pp. 535-340, Edited by J. Jeljaszewicz. Stuttgart : Gustav Fischer.

LyoN, B. R. \& SkURRAY, R. (1987). Antimicrobial resistance of Staphylococcus aureus: genetic basis. Microbiological Reviews 51, 88-134.

Maniatis, T., Fritsch, E. F. \& SambrooK, J. (1982) Molecular Cloning: a Laboratory Manual. Cold Spring Harbor, NY: Cold Spring Harbor Laboratory.

Mclaughlin, J. R., Murray, C. L. \& Rabinowitz, J. C. (1981). Unique features in the ribosome binding site sequence of the Gram-positive Staphylococcus aureus $\beta$-lactamase gene. Journal of Biological Chemistry 256, 11283-11291.

Messing, J., Gronenborn, B., MÜller-Hill, B. \& HOFSCHNEIDER, P. H. (1977). Filamentous coliphage M13 as a cloning vehicle: insertion of a HindIII fragment of the lac regulatory region into M13 replicative form in vitro. Proceedings of the National Academy of Sciences of the United States of America 74, 3642-3646.

MÉzes, P. S. F., WaNG, W., Yeh, E. C. H. \& LAMPEN, J. O. (1983). Construction of penPA1, Bacillus licheniformis 749/C $\beta$-lactamase lacking site for lipoprotein modification. Journal of Biological Chemistry 258, 11211-11218.

Nielsen, J. B. K. \& LAMPen, J. O. (1982). Membranebound penicillinases in Gram-positive bacteria. Journal of Biological Chemistry 257, 4490-4495.

Novick, R. P. (1963). Analysis by transduction of mutations affecting penicillinase formation in Staphylococcus aureus. Journal of General Microbiology 33, 121-136.

Novick, R. P. \& Bouanchaud, D. (1971). Extrachromosomal nature of drug resistance in Staphylococcus aureus. Annals of the New York Academy of Sciences 182, 279-294.

Novick, R. P. \& Richmond, M. R. (1965). Nature and interactions of the genetic elements governing penicillinase synthesis in Staphylococcus aureus. Journal of Bacteriology 90, 467-480.
Novick, R. P. \& Roth, C. (1968). Plasmid-like resistance to inorganic salts in Staphylococcus aureus. Journal of Bacteriology 95, 1335-1342.

PlüCKthun, A. \& KNowles, J. R. (1987). The consequences of stepwise deletions from the signalprocessing site of $\beta$-lactamase. Journal of Biological Chemistry 262, 3951-3957.

RosDAHL, V. T. (1973). Naturally occurring constitutive $\beta$-lactamase of novel serotype in Staphylococcus aureus. Journal of General Microbiology 77, 229231.

RichmoND, M. H. (1965a). Wild-type variants of exopenicillinase from Staphylococcus aureus. Biochemical Journal 94, 584-593.

RichmoND, M. H. $(1965 b)$. Dominance of the inducible state in strains of Staphylococcus aureus containing two distinct penicillinase plasmids. Journal of Bacteriology 90, 370-374.

Richmond, M. H. \& Sykes, R. B. (1973). The $\beta$ lactamase of Gram-negative bacteria and their possible physiological role. Advances in Microbial Physiology 9, 31-88.

Russell, M. \& Model, P. (1981). A mutation downstream from the signal peptidase cleavage site affects cleavage but not membrane insertion of phage coat protein. Proceedings of the National Academy of Sciences of the United States of America 78, 1717-1721.

Sanger, F., Nicklen, S. \& Coulson, A. R. (1977). DNA sequencing with chain-terminating inhibitors. Proceedings of the National Academy of Sciences of the United States of America 74, 5463-5467.

Shalita, Z., Murphy, E. \& Novick, R. P. (1980). Penicillinase plasmids of Staphylococcus aureus: structural and evolutionary relationships. Plasmid 3 291-311.

W ANG, P. Z. \& Novick, R. P. (1987). Nucleotide sequence and expression of the $\beta$-lactamase gene from Staphylococcus aureus plasmid pI 258 in Escherichia coli, Bacillus subtilis and Staphylococcus aureus. Journal of Bacteriology 169, 1763-1766.

Wilson, C. R., SkinNer, S. E. \& ShaW, W. V. (1981) Analysis of two chloramphenicol resistance plasmids from Staphylococcus aureus: insertional inactivation of chloramphenicol resistance, mapping of restriction sites and construction of cloning vehicles. Plasmid 5, 245-258.

Yanisch-Perron, C., Veira, J. \& Messing, J. (1985). Improved M13 phage cloning vectors and host strains: nucleotide sequences of the M13mp 18 and pUC19 vectors. Gene 33, 103-119. 